\title{
Binge Eating
}

National Cancer Institute

\section{Source}

National Cancer Institute. Binge Eating. NCI Thesaurus. Code C97162.

Recurrent episodes of over-eating. 